\title{
Antimicrobial Activity of Ethyl Acetate Fraction from Stelechocarpus burahol Fruit against Oral Bacteria and Total Flavonoids Content
}

\author{
Asni Amin ${ }^{1,3}$, Maksum Radji ${ }^{2}$, Abdul Mun'im ${ }^{3 *}$, Anton Rahardjo ${ }^{4}$, Herman Suryadi ${ }^{5}$ \\ 'Laboratory of Pharmacognosy and Phytochemistry, Faculty of Pharmacy, University Moeslem of Indonesia, INDONESIA. \\ 2Laboratory of Pharmaceutical Microbiology, Faculty of Pharmacy, Universitas Indonesia, INDONESIA. \\ 'Laboratory of Pharmacognosy and Phytochemistry, Faculty of Pharmacy, Universitas Indonesia, Depok, West Java, 16424, INDONESIA. \\ ${ }^{4}$ Department of Preventive and Public Health Dentistry, Faculty of Dentistry, Indonesia, INDONESIA. \\ 5Laboratory of Pharmaceutical Chemistry, Faculty of Pharmacy, Universitas Indonesia, Depok, West Java, 16424, INDONESIA.
}

\begin{abstract}
Objective: Stelechocarpus burahol is one of the native plants of Indonesia that has been used as an oral deodorant. This fruit contains flavonoids, which flavonoids are known to have antimicrobial activity against oral bacteria. The purpose of this study was to demonstrate the ethyl acetate fraction of $S$. burahol fruit to inhibit growth of oral bacteria and determine it the total flavonoid content. Methods: Antimicrobial activity test was performed againt oral bacteria (Porphyromonas gingivalis and Fusobacterium nucleatum) by disc diffusion and microdilution methods. The diffusion assay used Brucella Blood Agar (BBA) plate with paper disks soaked in the fraction of ethyl acetate $S$. burahol with various concentration $(1,2,4,8,10,20,40$, and $60 \% \mathrm{w} / \mathrm{v}$ ), the inhibitory zone diameter of each bacteria compared to standard catechins. The minimum inhibition concentration value (MIC) was using the microdilution method with brucella broth for bacterial growth medium. Total flavonoid content was measured by UVNisible spectrophotometer with standard quercetin at $440 \mathrm{~nm}$ wavelength. Results: The results showed that ethyl acetate fraction could inhibit the growth of $P$. gingivalis and $F$. nucleatum with concentration of $1 \% \mathrm{~W} / \mathrm{V}$, and the MIC
\end{abstract}

was $125 \mathrm{ug} / \mathrm{ml}$. The total flavonoid content is 0.833 extract $\mathrm{mg} / \mathrm{g}$ Quercetin Equivalent. Conclusion: The ethyl acetate fraction of $S$. burahol fruit contained flavonoid that can be used as antimicrobial against oral bacteria.

Key words: Antimicrobial, Total flavonoid content, Oral bacteria, Stelechocarpus burahol, Ethyl acetate fraction.

Key message: Ethyl acetate fraction of $S$. burahol fruit with flavonoid content can inhibit the growth of oral bacteria.

\section{Correspondence}

Abdul Mun'im, Laboratory of Pharmacognosy and Phytochemistry, Faculty of Pharmacy, Universitas Indonesia, Depok, West Java, 16424, INDONESIA.

Phone: +62 8111184550

Email: munimabdoel@gmail.com , icapps2017.farmasiui@gmail.com

DOI: 10.5530/jyp.2018.2s.19

\section{INTRODUCTION}

Traditional medicines especially sourced from natural products have been used to prevent, treat, and maintain human health for a long period of time. Most people living in the developing countries use the medicinal plant for primary healthcare and treat many diseases. ${ }^{1}$ Nowadays, the uses of traditional medicinal plants for developed as raw drug, new drug compounds, and pharmaceuticals product to health care have steadily increased worldwide, include oral healthcare product, ${ }^{2}$ but research and experiment about phytochemicals and pharmacological activity in medicine plant that could be useful as antimicrobials for treatment of infectious diseases, especially antimicrobial against oral bacterial very few and limited data. ${ }^{3}$ One of the medicine plants that have potential for oral care is Stelechocarpus burahol (Blume) Hook.f. and Thomson. The fruit belonging to family Annonaceae is a traditional herbal medicine in Indonesia, which is commonly found in Java Island, especially Central of Java. These fruit was reported has antibacterial and anti-inflammatory activity. The fruits have been empirically used by the princeses of Yogyakarta Palace for removal oral malodor (halitosis). ${ }^{5-6}$ Halitosis is oral diseases in human, commonly derives from the proteolytic activity of Gram negative anaerobic oral bacteria associated with food metabolism, which the bacteria have a role in degrading the food became amino acids containing sulfide to produce Volatile Sulphur Compounds (VSCs)..$^{7-8}$ The S. burahol fruit extracts may inhibit and reduce VSCs causing halitosis, which it is produced by bacteria $P$. gingivalis and F. nucleatum. The antimicrobial test from $S$. burahol extract mouthwash has been reported and the results show the mouthwash did not exhibit antimicrobial activity against $P$. gingivalis. ${ }^{5-6}$

P. gingivalis and F. nucleatum are pathogenic bacteria that grow in the oral cavity associated oral disease. Both of these bacteria play an important role as the cause of periodontal disease. $P$. gingivalis are Gram negative anaerobic known as black pigmented bacteria that usually cause gingivitis. Fusobacterium nucleatum belong to the oral microbiota, more commonly found in the oral cavity, in gingival pockets as periodontal disease progresses. ${ }^{9-10}$

Based on phytochemical identification data, it is known that the fraction of ethyl acetate of $S$. burahol contains the components of polyphenols and flavonoids. ${ }^{6}$ The polyphenols have been reported antimicrobial activity against oral bacteria to treat dental and periodontal disease. Polyphenols in foods such as red grape skins and green tea were reported can inhibit the growth of oral bacteria that cause periodontitis. ${ }^{11-12}$ Apigenin, galangin, flavone and flavonol glycosides, isoflavones, flavanones, and chalcones, includes a group of flavonoid compounds have been shown to possess potent antimicrobial activity. In addition, some other flavonoids such as quercetin, phlorin, naringin, have activity as an oral antibacterial by inhibiting the growth of Gram negative anaerobic bacteria 
associated with periodentitis such as Protovella intermedia, P. gingivalis, Actimicitans, F.nucleatum, Solanum morei. ${ }^{13-14}$

Based on the results of in vitro study and still limited information about the antimicrobial properties of $S$. burahol fruit against oral bacteria, we want to investigate the antimicrobial activity of the ethyl acetate fraction against oral bacteria and the total flavonoids assay contained in this fruit.

\section{MATERIALS AND METHODS}

\section{Plant material}

The ripe fruit of $S$. burahol was collected from smallholder estates in Magelang, Central Java, Indonesia. Harvest time is February-March. The fruit flesh was separated from the pericarp of the fruit and the seeds, the fruit flesh was sliced thin and dried at $40^{\circ} \mathrm{C}$. Dried fruits powdered and weighed. The sample was ready for the extraction process.

\section{Preparation of S. burahol fraction}

Preparation fraction was conducted according partition procedure by Amin et al and Mun'im et al. procedure. ${ }^{5-6}$ Burahol fruit extracted with conventional method by maceration extraction used ethanol solvent. ${ }^{15}$ The ethanol extract was dispersed in warm water and ethanol $(30.70 \mathrm{ml})$ and partitioned successively with $\mathrm{n}$-hexane solvent to obtain liquid hexane fraction. The residue is re-partitioned with an ethyl acetate solvent. The organic layer is concentrated in a rotary vacuum evaporator under reduced pressure at $50^{\circ} \mathrm{C}$, to obtain concentrated hexane and ethyl acetate fractions.

\section{The Culture of the Bacterial strains.}

Oral bacteria were employed in this study including two species Gram negative anaerobic: $P$. gingivalis ATCC 33277, and Fusobacterium nucleatum ATCC 25586. Both were cultured in Brucella Blood Agar (BBA) (Difco) medium with the addition of vitamin $\mathrm{K}$ and kanamycin, after incubated at $37^{\circ} \mathrm{C}$ for $72 \mathrm{~h}$ under anaerobic condition.

\section{Antimicrobial Activity Assay}

Antimicrobial activity assay using disc diffusion method: Petri plates were prepared with $20 \mathrm{~mL}$ of sterilized BBA+vit K, then solidified. Bacterial test colonies were suspended in $0.9 \%$ saline and adjusted to $0.5 \mathrm{Mc}$ Farland turbidity standard (equivalent to approximately 1-7x106 CFU/ml). $100 \mu \mathrm{l}$ of each bacterial solution was swabbed onto the plates, and allowed to stand for $15 \mathrm{~min}$. The sterile paper disk blank ( $6 \mathrm{~mm}$ diameter disc) was impregnated with the various concentration of sample $(1,2,4,8,10,20$, $40,60 \mathrm{mg} / \mathrm{ml}$ per disc), sterile distilled water as a negative control, and catechin as the positive control. The loaded discs were placed on the surface of the agar plate. The plates were incubated for $72 \mathrm{~h}$ at $37^{\circ} \mathrm{C}$ in anaerobic condition. The results were evaluated by measuring the diameter of the growth inhibition zones formed around each disc. All experiments were done in triplicate. ${ }^{16}$

\section{Minimum Inhibitory Concentration and Minimum Bactericide Concentration.}

The minimum inhibitory concentration (MIC) assay using microdilution method, ${ }^{17}$ it was performed according to the protocol of Scorzoni, et al. ${ }^{18}$ with some modification: The burahol fraction was dissolved in water and $2 \%$ DMSO. The various concentration sample $(1,2,4,8$, and $10 \mu \mathrm{g} / \mathrm{ml})$ were inserted into each well with a total volume of $100 \mu \mathrm{l}$ per well in the 96-well plates. Each microtiter plate well was inoculated with $5 \mu \mathrm{L}$ of $0.5 \mathrm{McF}$ arland standard broth bacteria (equivalent to approximately $1-7 \times 10^{6} \mathrm{CFU} / \mathrm{ml}$ ) was diluted to the ratio of 1:100 in BHI (Merck) broth media. The mixture was incubated anaerobically at $37^{\circ} \mathrm{C}$ for $24 \mathrm{~h}$. Absorbance reading at $520 \mathrm{~nm}$ wavelength using a microtiter plate reader and cell growth measured post-incubation. DMSO as the negative control, while catechin as the positive control. Minimum inhibitory concentration (MIC) values were evaluated by observing the turbidity and the absorbance reading of the suspension post-incubation. The lowest concentrations of burahol fruit fraction without visible growth with clear suspension were defined as minimum concentrations that inhibited bacterial growth (MIC). To confirm the Minimum Bactericide Concentration $(\mathrm{MBC})$, the suspension samples after incubation were transferred to plate of BBA (conventional plating method) and anaerobically incubated for $3 \times 24$ h. The lowest concentration with no visible growth was defined as the MBC. The experiment was performed in triplicates.

\section{Total Flavonoid Content Assay}

The total flavonoid content (TFC) was conducted according to using the aluminum chloride colorimetric method with some modification. The fraction was dissolved in $10 \mathrm{ml}$ methanol, $0.5 \mathrm{ml}$ of extract solutions were mixed with $2 \mathrm{~mL}$ of distilled water, and added $0.2 \mathrm{ml}$ of $10 \% \mathrm{AlCl}_{3}$ solution, $0.2 \mathrm{~mL}$ of $1 \mathrm{M}$ sodium acetate, and volume was made up to 5 $\mathrm{ml}$ with distilled water, vortex for $2 \mathrm{~min}$ and left at room temperature for $30 \mathrm{~min}$. The mixture solution incubated for $1 \mathrm{~h}$. The absorbance of the reaction mixture was measured at $440 \mathrm{~nm}$ with UV/Visible spectrophotometer. The total flavonoid contents were calculated as quercetin from a calibration curve with the solution concentrations of 10 to $60 \mathrm{mg} / \mathrm{ml}$ in methanol. The TFC was expressed in mg of quercetin equivalents per Gram of extract. All the measurements were performed in triplicates. ${ }^{19}$

\section{RESULTS}

\section{Antimicrobial Activity Assay}

Antimicrobial activity of ethyl acetate fraction of $S$. burahol fruit to oral bacteria using diffusion method showed that fraction with concentration $1 \mathrm{mg} / \mathrm{ml}$ can inhibit the growth of F. nucleatum bacteria with the diameter of inhibition zone is $8.13 \mathrm{~mm}$, while $P$. gingivalis have diameter of inhibition zone is $\geq 9 \mathrm{~mm}$. The catechin as positive control shows the diameter of inhibition zone is $\geq 10 \mathrm{~mm}$. The results are shown in Table.1.

\section{Minimum Inhibition Concentration and Minimum Bactericidal Concentration Assay}

The determination of MIC, and MBC values using microdilution method. The lowest concentration of burahol fruit fraction for inhibiting the growth of $P$. gingivalis and F.nucleatum was determined as the MIC. The range of MIC of the fraction recorded was $0.1-1 \mathrm{mg} / \mathrm{ml}$.

The fruit fraction showed MIC of $0.1 \mathrm{mg} / \mathrm{ml}$, whereas catechin as positive control showed MIC of $0.2 \mathrm{mg} / \mathrm{ml}$. DMSO as negative control. The MBC assay cannot be determined by microdilution because the dark/brown color in the test sample makes the turbidity, so the MBC value undetermined, to confirm $\mathrm{MBC}$ the suspension samples were transferred to plate of BBA+vit K media. The fruit fraction showed $\mathrm{MBC}$ of $1 \mathrm{mg} / \mathrm{ml}$. The results is shown in Table 2 .

\section{Total Flavonoid Content Assay}

The total flavonoid content (TFC) was conducted using the aluminum chloride colorimetric that calculated of quercetin equivalent. The result is shown in Table 3.

\section{DISCUSSION}

Natural product has long been known and used as traditional medicine to treat and maintenance of human health. The natural product with antimicrobial activity could become a potential source of new drugs. Today, the antimicrobial activity study of medicinal plant against oral pathogen has been many reported. The Gram negative anaerobic oral 
Table 1: Antimicrobial activities of ethyl acetate fractions of $S$. burahol fruit in Disc Diffusion Method.

\begin{tabular}{cccc}
\hline \multirow{2}{*}{ Antimicrobial } & $\begin{array}{c}\text { Concentration } \\
\text { per disc }(\mathrm{mg} / \mathrm{ml})\end{array}$ & \multicolumn{2}{c}{$\begin{array}{c}\text { Diameter of inhibition zones } \\
\text { (The mean } \pm \text { SD in } \mathrm{mm} \text { ) }\end{array}$} \\
\cline { 3 - 4 } & & P.gingivalis & F.nucleaum \\
\hline S. burahol & 1 & $8.13 \pm 0.25$ & $9.46 \pm 0.44$ \\
Fruit & 2 & $9.17 \pm 0.39$ & $10.36 \pm 0.26$ \\
& 4 & $10.06 \pm 0.40$ & $10.83 \pm 0,26$ \\
& 8 & $10.57 \pm 0.36$ & $10.95 \pm 0.35$ \\
& 10 & $10.66 \pm 0.58$ & $11.37 \pm 0.33$ \\
& 20 & $11.18 \pm 0.65$ & $11.78 \pm 0.40$ \\
& 40 & $11.54 \pm 0.53$ & $12.35 \pm 0.44$ \\
Catechin & 60 & $13.33 \pm 0.35$ & $13.53 \pm 0.54$ \\
& 3 & $10.11+0.23$ & $10.11+0.23$ \\
\hline
\end{tabular}

Table 2: MIC and MBC values in microdilution methods.

\begin{tabular}{ccccc}
\hline \multirow{2}{*}{ Antimicrobials } & \multicolumn{2}{c}{ P. gingivalis } & \multicolumn{2}{c}{ F. nucleaum } \\
\cline { 2 - 5 } & $\begin{array}{c}\text { MIC values } \\
(\mathrm{mg} / \mathrm{ml})\end{array}$ & $\begin{array}{c}\text { MBC values } \\
(\mathrm{mg} / \mathrm{ml})\end{array}$ & $\begin{array}{c}\text { MIC values } \\
(\mathrm{mg} / \mathrm{ml})\end{array}$ & $\begin{array}{c}\text { MBC values } \\
(\mathrm{mg} / \mathrm{ml})\end{array}$ \\
\hline S. burahol fruit & 0.1 & - & 0.1 & - \\
& 0.2 & - & 0.2 & - \\
& 0.4 & - & 0.4 & - \\
Catechin & 0.8 & - & 0.8 & - \\
\hline
\end{tabular}

(-): There is no colony growth, MIC: Minimum Inhibition Concentration, MBC: Minimum Bactericidal Concentration.

Table 3: The Total Flavanoid Content (TFC) From Fraction of S. burahol Fruit.

\begin{tabular}{cccc}
\hline Sample & $\begin{array}{c}\text { Concentration } \\
(\mu \mathrm{g} / \mathrm{ml})\end{array}$ & $\begin{array}{c}\text { Absorbance } \\
\text { Value }\end{array}$ & $\begin{array}{c}\text { TFC } \\
(\mathrm{mg} \mathrm{QE} / \mathrm{gm})\end{array}$ \\
\hline EAF of $S$. burahol & 5000 & $0.079 \pm 0.0130$ & $0.833 \pm 0.013$ \\
\hline
\end{tabular}

EAF: Ethyl acetate fraction, the total flavonoid content (TFC) was determined as mean \pm SD for triplicates measurements.

pathogen known as causative oral diseases, especially periodontal diseases. $^{7-8}$ Several medicinal plants belongs to the family of Fabaceae, Ebenaceae, Bombaceae and Annonaceae has been reported for treatment of oral diseases..$^{20} \mathrm{~S}$. burahol is one of some Indonesian indigenous plants belonging to family Annonaceae. These fruit have been traditionally used as body deodorant and oral deodorant by the princess of Yogyakarta Palace. As an oral deodorant, the burahol fruit extracts have been studied by in-vivo and in vitro test, the result of this study prove that the extracts have the ability to reduce volatile sulfur compounds (VSCs) that trigger halitosis. ${ }^{4-6}$ Halitosis or oral malodor derives from the proteolytic activity of Gram negative anaerobic oral bacteria. ${ }^{7}$ The antimicrobial tests against Gram negative anaerobic bacteria are performed as one step to reduce oral malodor with inhibiting growth oral bacteria. Antimicrobial activity of $S$. burahol of mouthwash extract against $P$. gingivalis (Gram negative anaerobic oral bacteria) showed no antimicrobial activity, ${ }^{5}$ but in vitro studies to reduce VSC reported that ethyl acetate fraction could inhibit and reduce VSC from methyl mercaptan produced by Gram negative anaerobic bacteria from physiologic halitosis saliva, ${ }^{6}$ this being an indication that $S$. burahol has potential as an antimicrobial against oral pathogens. The hexane fraction was not tested in this study because previous research revealed that the hexane fraction is inactive to reduce (VCS). ${ }^{5-6}$ The ethyl acetate fraction was tested for two anaerobic gramnegative bacteria, such as $P$. gingivalis and $F$. nucleatum. Both of these bacteria belong to oral pathogenic bacteria as the cause of oral disease. The antimicrobial activity of the $S$. burahol fruit fraction was carried out using the method for agar disk diffusion, the advantage of this method was simple, low cost and the use of small sample volumes. The antimicrobial activity of this fraction belongs to moderate activity with inhibition zone diameter at the concentration range of 2 to $40 \mathrm{mg} / \mathrm{ml}$ is $\geq 10 \mathrm{~mm}$. The MIC was defined as the lowest concentration able to inhibit any visible bacteria growth. The results were analyzed visually and spectrophotometrically. The MIC results indicated that the fraction is potentially antimicrobial to oral pathogenic bacteria with the lowest inhibitory concentrations is $0.1 \mathrm{mg} / \mathrm{ml}$ of two Gram negative anaerobic oral bacteria tested.

Based on the results of phytochemical tests, it was reported that the fraction of ethyl acetate contains polyphenols and flavonoids. The total flavonoid content of the ethyl acetate fraction is expressed as a total flavonoid value that is equivalent to quercetin. The phenolic compound has potency as antimicrobial property to inhibit oral bacteria, such as allyl pyrocatechol from betel leaves, catechin from green tea and resveratrol from licorice inhibit anaerobic oral bacteria and reduce malodor. ${ }^{11}$ Catechins include epicatechin, epicatechingallate, and epigallocatechin gallate found in Camelia sinensis (Theaceae) are believed to be responsible for the oral antimicrobial activity, prevention of adherence of bacteria to tooth surfaces, inhibition of glucan production and inhibition of amylases. ${ }^{12}$ Several polyphenols have been reported as antimicrobial activity against periodontal pathogen. Wine catechins have strong antimicrobial activity against $P$. gingivalis and $P$. intermedia. ${ }^{11}$ Green tea catechins, used in a slow-release local delivery strip system applied in the periodontal pockets, decrease the pocket depth and the proportion of Gram negative anaerobic black pigment, while the same catechins show an in vitro bactericidal effect against $P$. gingivalis and Prevotella spp. Several polyphenols inhibit the proteolytic activity of $P$. gingivalis. ${ }^{21}$

Flavonoids are classified under phenolic groups in plants, which have been reported to be effective as antimicrobial property against a wide array of microorganisms with some mechanisms: inhibition of nucleic acid synthesis, cytoplasmic membrane function, and energy metabolism. Several flavonoids including apigenin, galangin, flavone and flavonol glycosides, isoflavones, flavanones and chalcones have been shown to possess potent antimicrobial activity. The citrus fruit was shown to inhibit the growth of periodontal pathogens and other common oral microorganisms, such as Actinobacillus actinomycetemcomitans and $P$. gingivalis because flavonoid compound in the fruit such as naringin indicates as antimicrobial activity against oral pathogen. Phlorin is a phenolic compound in lemon peel exhibited antimicrobial activity against oral bacteria, such as P. intermedia, S. mutans and P. gingivalis. Quercetin may inhibit oral bacteria, such as S. mutans, S. sobrinus, $S$. sanguis, L. acidophilus that associate cariogenic diseases. It also inhibits oral pathogens $P$. gingivalis, and A. actinomycetemcomitans as the main causative agent of periodontal disease. ${ }^{22}$ The mechanism of antimicrobial activity of quercetin by disrupting the membrane and inactivating the extracellular protein by forming irreversible complexes. ${ }^{11}$ Several studies have shown that isoflavones, flavones, isoprenylflavones flavanones, narigenin, and quercetin may inhibit cariogenic bacteria such as Streptococcus spp, Actinobacillus, and Lactobacillus species.

The present study report that the ethyl acetate fraction of $S$. burahol fruit showed antimicrobial activity against oral pathogens. The polyphenolic and flavonoids compounds in this fruit indicate those antimicrobial properties may inhibit the growth of Gram negative anaerobic oral pathogenic 
causes of periodontal and other oral diseases. The antimicrobial mechanism is suspected by disrupting of the membrane and inactivate extracellular proteins or by inhibition of nucleic acid synthesis, and energy metabolism.

\section{CONCLUSION}

The ethyl acetate fraction of $S$. burahol has antimicrobial property against oral bacteria associated with oral disease, which can inhibit the growth of oral bacteria such as $P$. gingivalis and F. nulceatum bacteria, with flavonoids contained in this fruit.

\section{ACKNOWLEDGEMENT}

This research was supported by Ministry of Research, Technology, and Higher Education, Republic of Indonesia.

\section{CONFLICT OF INTEREST}

The authors declare no conflict of interest.

\section{ABBREVIATIONS}

BBA: Brucella Blood Agar; MIC: Minimum Inhibition Concentration; MBC: Minimum Bactericide Concentration; VSCs: Volatile Sulphur Compounds; ATCC: American Type Culture Collection.

\section{SUMMARY}

Ethyl acetate fraction of Stelechocarpus burahol fruit inhibited the growth of anaerobic bacteria causing bad breath such as Porphyromonas gingivalis and Fusobacterium nucleatum. Total flavonoid content. The total flavonoid content is 0.833 extract mg / g Quercetin Equivalent.

\section{REFERENCES}

1. Martins Ek. The growing use of herbal medicines: Issues relating to adverse reactions and challenges in monitoring safety. Front Pharmacol. 2013;4:177. DOI:10.3389/fphar.2013.00177

2. Nascimento GG, Locatelli J, Freitas PC, Silva G L. Antimicrobial Activity of Plant Extracts and Phytochemicals on Antibiotic resistant Bacteria. Braz J Microbiol. 2000;31(4):247-56

3. Perumal Samy R, Gopalakrishnakone P. Therapeutic Potential of Plants as Anti-microbials for Drug Discovery, Evid Based Complement Alternat Med. 2010;7(3):283-94. doi: 10.1093/ecam/nen036

4. Darusman H, Rahminiwati M, Sadiah S, Batubara I, Darusman L, Mistunaga T.
Indonesian kepel fruit (Stelecocarpus burahol) as oral deodorant. J Med Plant. 2012;6(2):180-8.

5. Mun'im A, Siswanto BD, Negishi O, Sutriyo, Amin A, Rahardjo A. Effect of burahol (Stelechocarpus burahol (Blume) Hook F and Thomson) fruits extract mouthwash on mouth bad deodorization. Indian J Tradit Knowl. 2017;16(3):431-6.

6. Amin A, Radji M, Mun'im A, Rahardjo A, Suryadi $H$. Halitosis activity against volatile sulfur compound of methyl mercaptan component from burahol (Stelechocarpus burahol) fruit extract. Asian J Pharm Clin Res. 2017;10(5):116-9.

7. Scully C, Greenman J. Halitosis (breath odor). J Periodontology. 2000;48(2008):66-75.

8. Jenkinson HF, Lamont RJ. Oral microbial communities in sickness and in health. Trends in Microbiol. 2005;13(12):589-95.

9. Rodrigues PH, Carvalho SA, Costa JE, Carvalho MA, Farias LM, Petrillo-Peixoto ML. Black-pigmented Gram negative anaerobic in Brazilian adults with peridontal disease. Anaerobe. 1999;5(3-4):267-8

10. Bolstad Al, Jensen HB, Bakken V. Taxonomy, biology, and periodontal aspects of Fusobacterium nucleatum. Clin Microbiol Rev. 1996;9(1):55-71.

11. Pettia S, Scully C. Review Polyphenols, oral health and disease: A review. J Dentistry. 2009;37(6):413-23.

12. Kakuda T, Takihara T, Sakane I, Mortelmans K. Antimicrobial activity of tea extracts against periodontopathic bacteria., Nippon Nôgeikagaku Kaishi. 1994;68(2):241-3.

13. Tsuchiya $H$, Sato M, Miyazaki T, Fujiwara S, Tanigaki S, Ohyama M, et al Comparative study on the antimicrobial activity of phytochemical flavanones against methicillin-resistant Staphylococcus aureus. J Ethnopharmacol. 1996;50(1):27-34

14. Cushnie TPT, Lamb AJ. Antimicrobial activity of flavonoids, Int J Antimicrob Agents. 2005;26(5):343-56.

15. Ahmad I, Yanuar A, Mulia K, Abdul Mun'im. Application of ionic liquid as a green solvent for polyphenolics extraction. J Young Pharm. 2017;9(4):486-90.

16. Chandrashekar BR, Nagarajappa $R$, Singh $R$, Thakur $R$. An in vitro study on the anti-microbial effi cacy of ten herbal extracts on primary plaque colonizers. J Young Pharm. 2014;6(4):33-9.

17. Harsha L. Lakshmi Thangavelu. Screening of ethanolic extracts of medicinal herbal drugs against oral microbes, Pharmacogn J. 2017; 9(2):201-203

18. Scorzoni L, BenaducciT, Almeida AM, Silva DH, Bolzani VS, Mendes-Giannini MJ. Comparative study of disk diffusion and microdilution methods for evaluation of antifungal activity of natural compounds against medical yeasts Candida spp and Cryptococcussp, Rev. Ciênc. Farm Básica Apl. 2007;28(1):25-34

19. Budiman A, Aulifa DL, Kusuma AS, Astri Sulastri. Antibacterial and Antioxidant Activity of Black Mulberry (Morus nigra L.) Extract for Acne Treatment, Pharmacogn J. 2017;9(5):611-4

20. Hadissa T, Jean-Pierre D. Use of medicinal plants for treatment of oral diseases in Burkina Faso. J Ethnopharmacol. 2006;104(1-2):68-78.

21. Hirasawa M, Takada K, Makimura M, Otake S. Improvement of periodontal status by green tea catechin using a local delivery system: A clinical pilot study. J Periodontal Res. 2002;37(6):433-8.

22. Yi Shu, Yi Liu, Li Li, Jin Feng, Beiyan Lou. Xuedong Zhou and Hongkun Wu. Antimicrobial activity of quercetin on oral infectious pathogens. Afr J Microbiol Res. 2011;5(30):5358-61. 